\title{
Studi Batimetri dan Topografi Dasar Laut untuk Penentuan Jalur Peletakanan Kabel Bawah Laut di Perairan Lampung - Pulau Pahawang
}

\author{
Ma'ariq Badrutamam S.*, Alfi Satriadi, Aris Ismanto \\ Departemen Oseanografi, Fakultas Perikanan dan Ilmu Kelautan, Universitas Diponegoro \\ Jl. Prof. H. Sudarto, SH, Tembalang Semarang. 50275 Telp/fax (024)7474698 \\ Email: *maariqbadrutamams@gmail.com
}

\begin{abstract}
Abstrak
Energi listrik sangat dibutuhkan untuk berbagai macam keperluan seiring dengan perkembangan dinamika kehidupan masyarakat. Untuk mengantisipasinya direncanakan pembangunan daya pasokan listrik melalui kabel bawah laut dari Lampung menuju Pulau Pahawang. Tujuan dari penelitian ini untuk mengetahui kedalaman dan morfologi dasar laut pada lokasi penelitian serta menentukan jalur kabel bawah laut berdasarkan data tersebut. Jalur pemasangan kabel bawah laut dimulai dari landing point Lampung, berlanjut melintasi laut menuju landing point Pulau Pahawang. Dalam merancang jalur pemasangan kabel bawah laut, metode yang digunakan berupa metode survei berupa observasi lapangan dengan data berupa data batimetri dan side scan sonar menggunakan echosounder singlebeam dan SSS Humminbird Helix 12 Chirp Mega SI GPS G2N, topografi dasar laut dan informasi sedimen dasar di sepanjang rencana koridor jalur kabel laut menggunakan sedimen grab serta data pasang surut pada tanggal 12 Juli 2019. Pengolahan data menggunakan perangkat lunak Reef Master 2.0 dan Surfer 11. Hasil dari penelitian ini adalah jalur kabel bawah laut dari landing point Lampung ke landing point Pulau Pahawang dengan panjang kabel 1406.77 meter. Kedalaman air laut di lokasi penelitian -0.5 hingga -25 meter dengan topografi permukaan dasar laut bergelombang dengan kemiringan $6.48^{\circ}$ dan memiliki sedimen dasar laut yang didominasi oleh lanau dan pasir.
\end{abstract}

Kata kunci : Batimetri, Kabel Bawah Laut, Topografi Dasar Laut

\begin{abstract}
Electrical power is needed for various purposes along with the development of the dynamics of community life. To fix this issue, the planned construction of electricity supply through the submarine cable in Lampung to Pahawang Island. This development planning is carried out by conducting surveys related to the seabed to determine cable lines. The aim of this research to determine the depth and morphology of the seabed and determine the submarine cable lines based on these data. Route of submarine cable starts from the Lampung landing point, continues across the sea towards the Pahawang Island landing point. Designing the submarine cable route, method used is a survey method in the form of field observations used data of bathymetry and side scan sonar using a singlebeam echosounder and SSS Humminbird Helix 12 Chirp Mega SI GPS G2N, seabed topography and information of sediments along the corridor plans cable using grab sediment and tidal data on July 12, 2019. Data processing using Reef Master 2.0 and Surfer 11 Software. The results of this research are submarine cable route from the Lampung landing point to Pahawang Island landing point having a cable length of 1406.77 meters. Seawater depth in research location - 0.5 to - 25 meters with a wavy seabed surface topography with a slope of $6.48^{\circ}$ and has a seabed sediment dominated by silt and sand.
\end{abstract}

Keywords : Bathymetry, Seabed Topography, Submarine Cable 


\section{PENDAHULUAN}

Indonesia merupakan salah satu negara kepulauan terbesar di dunia dengan 16.056 pulau (Badan Pusat Statistik, 2018) dan garis pantai sepanjang $99.093 \mathrm{~km}$ (Kementerian Kelautan dan Perikanan, 2018). Untuk meningkatan perekenomian seluruh pulau di Indonesia, perlu adanya pemerataan infrastruktur baik berupa jalan, sistem telekomunikasi hingga kebutuhan energi listrik. Namun, masih banyak pulau-pulau kecil di Indonesia yang belum memiliki fasilitas infrastruktur yang mumpuni, khususnya untuk memenuhi kebutuhan listrik pulau tersebut (Fitra dan Asirin, 2018). Pulau Pahawang merupakan pulau yang terletak di kawasan Teluk Punduh yang berada di Kecamatan Punduh Pidada Kabupaten Pesawaran, Lampung. Pulau Pahawang termasuk dalam salah satu destinasi wisata yang cukup terkenal dan menjadi sumber pendapatan utama masyarakatnya. Seiring dengan meningkatnya kunjungan wisatawan ke Desa Pulau Pahawang, menyebabkan perlunya infrastruktur tambahan guna memenuhi kebutuhan energi listrik pulau tersebut, hal ini dikarenakan listrik hanya menyala 8 jam sehari melalui pembangkit diesel, sehingga masyarakat dan wisatawan yang berkunjung hanya dapat menikmati listrik mulai pukul $21.00-05.00$ WIB. Oleh sebab itu PT.PLN (Persero) mengadakan pekerjaan pembangunan kabel laut $20 \mathrm{kV}$ antara landing point Lampung - Pulau Pahawang guna menunjang kebutuhan energi listrik pulau tersebut.

Dalam pekerjaan pembangunan kabel laut Lampung - Pulau Pahawang diperlukan penelitian berupa survei untuk mengetahui kondisi dasar perairan serta penentuan jalur peletakan kabel bawah laut. Pembangunan kabel laut dilakukan dengan cara pemendaman di bawah permukaan dasar laut (DNV, 2016). Dalam penentuan jalur kabel bawah laut salah satu faktor yang dibutuhkan dan dipertimbangkan yaitu karakteristik dasar laut (seabed characteristic), dengan demikian perlu dilakukan penelitian spesifik mengenai kedalaman laut (batimetri) serta karakteristik sedimen dasar untuk memperoleh gambaran topografi di sepanjang koridor jalur kabel laut.

Tujuan dari penelitin ini adalah untuk mengetahui kedalaman dan morfologi dasar laut pada lokasi penelitian serta menentukan jalur kabel bawah laut berdasarkan data tersebut. Survei batimetri dan side scan sonar dilakukan dengan menggunakan singlebeam echosounder dan SSS Humminbird Helix 12 Chirp Mega SI GPS G2N. Data penelitian akan ditampilkan dalam bentuk peta kontur kedalaman dan peta 3D dengan menggunakan data batimetri yang telah dikoreksi dengan pasang surut di perairan tersebut. Data side scan sonar ditampilkan dalam peta side scan sonar dan diverifikasi dengan data sedimen dasar untuk mengetahui jenis sedimen dominan pada lokasi tersebut. Pengolahan data dilakukan dengan perangkat lunak Reef Master 2.0, Civil 3D, ArcGIS 10.3 dan Surfer 11.

\section{MATERI DAN METODE \\ Materi Penelitian}

Materi yang digunakan dalam penelitian ini meliputi data utama yaitu data batimetri, data side scan sonar, data sedimen dasar dan data pasang surut yang diperoleh secara langsung dengan metode survei lapangan di perairan Lampung - Pulau Pahawang. Data penunjang berupa Peta Rupa Bumi Indonesia Skala 1:25000 tahun 2018 dari BIG dan Data karakteristik kabel bawah laut berdasarkan PM 129 Tahun 2016 Tentang alur pelayaran di laut.

\section{Metode Penelitian}

Metode yang digunakan dalam penelitian ini adalah metode kuantitaif yang merupakan suatu cara untuk memperoleh data berupa angka-angka serta analisis statistik. Metode kuantitatif dalam penelitian ini akan menghasilkan data kedalaman yang diperoleh dari pemeruman dengan menggunakan singlebeam echosounder, data pengukuran pasang surut dengan palem pasut dan di verifikasi dengan data pasang surut 31 hari BIG pada stasiun Pelabuhan Panjang - Lampung, serta data sedimen dasar dengan grab sampler.

\section{Metode Pengambilan Data}

Pengambilan data batimetri, side scan sonar dan pasang surut dilakukan pada tanggal 12 Juli 2019 di perairan Lampung - Pulau Pahawang dengan menggunakan singlebeam echosounder dan SSS Humminbird Helix 12 Chirp Mega SI GPS G2N. Pengamatan pasang surut dilakukan selama satu hari selama pengambilan data batimetri dengan interval 60 menit pada koordinat $105^{\circ} 12^{\prime} 25.60^{\prime \prime} \mathrm{E}$ dan 
$5^{\circ} 39^{\prime} 12.62$ " $\mathrm{S}$ dengan menggunakan palem pasut. Pengambilan sampel sedimen dilakukan secara langsung dengan penyelaman dan grab sampler sepanjang koridor jalur kabel laut sebanyak 7 sampel.

\section{Metode Pengolahan dan Analisis Data \\ Batimetri}

Pengolahan data batimeri dilakukan dengan menggunakan software Reef Master 2.0. Pengolahan data batimetri meliputi koreksi oseanografi (pasang surut) real time, edited data, sorted data dan interpolation yang menghasilkan interpretasi kedalaman perairan. Bentuk permukaan dasar laut diketahui dengan dibuat model 3D topografi dasar laut menggunakan software Surfer 11. Hasil dari data analisis berupa peta kontur dan model 3 dimensi yang diketahui kondisi batimetri pada lokasi penelitian.

\section{Pasang Surut}

Data pasang surut lapangan di verifikasi dengan data pasang surut dari BIG pada stasiun pengamatan Pelabuhan Panjang, Lampung dan diolah dengan menggunakan metode Admiralty, sehingga memperoleh nilai komponen harmonik pasang surut air laut $\left(\mathrm{S}_{0}, \mathrm{M}_{2}, \mathrm{~S}_{2}, \mathrm{~N}_{2}, \mathrm{~K}_{2}, \mathrm{~K}_{1}, \mathrm{O}_{1}, \mathrm{P}_{1}, \mathrm{MS}_{4}\right.$ dan $\mathrm{M}_{4}$ ), sehingga dapat dihitung nilai Formzahl untuk mengetahui tipe pasang surut dan nilai MSL sebagai koreksi data kedalaman laut untuk memperoleh kedalaman laut sebenarnya.

\section{Kemiringan Dasar Laut}

Pengklasifikasian nilai kemiringan lereng didasarkan pada klasifikasi Van Zuidam (1985) dengan menghitung kemiringan (slope) menggunakan peta kontur batimetri dari hasil pengolahan data batimetri. Perhitungan kemiringan dasar laut menggunakan persamaan seperti berikut:

\section{$\operatorname{Tan} \alpha=\Delta \mathbf{H} / \mathbf{L}$}

\section{Keterangan :}

$\alpha \quad$ : besarnya sudut $\left({ }^{\circ}\right)$ kemiringan dasar laut (slope)

$\Delta \mathrm{H}$ : elevasi yang diperoleh antara dua kontur batimetri (m)

L : jarak horizontal (tegak lurus) antara kedua garis kontur batimetri (m).

Tabel 1. Klasifikasi Kemiringan (slope) Van Zuidam (1985) pada bentang alam wilayah tropis

\begin{tabular}{lcc}
\hline \multicolumn{1}{c}{ Sifat } & Kelas Lereng (\%) & Morfologi $\left(^{\circ}\right)$ \\
\hline Datar hingga hampir datar & $0-2 \%$ & $0-2^{\circ}$ \\
Agak miirng atau landai & $2-7 \%$ & $2-4^{\circ}$ \\
Miring dengan besaran yang tinggi atau & $7-15 \%$ & $4-8^{\circ}$ \\
bergelombang & $15-30 \%$ & $8-16^{\circ}$ \\
Agak curam & $30-70 \%$ & $16-35^{\circ}$ \\
Curam & $70-140 \%$ & $35-55^{\circ}$ \\
Sangat curam & $7>140 \%$ & $>55^{\circ}$ \\
Curam sekali & & \\
\hline
\end{tabular}

\section{Side Scan Sonar}

Pengolahan data side scan sonar dilakukan menggunakan software Reef Master 2.0. Interpretasi side scan sonar yang baik dapat dihasilkan dari citra yang telah dilakukan koreksi berupa koreksi slant range correction untuk menghilangkan blind zone serta menghilangkan bagian perekaman yang berkelok dan koreksi Automatic gain control untuk memberikan gambaran sebenarnya pada citra side scan sonar sehingga dapat diinterpretasi secara visual. Interpretasi dilakukan berdasarkan pada bentuk, ukuran dan derajat kehitaman pada obyek.

\section{Data Sedimen Dasar Laut}

Pengolahan data sedimen dasar dilakukan dengan metode analisis ukuran butir dengan dry shieving (pengayakan) dan wet shieving (pemipetan). Sedimen dasar lumpur dianalisis dengan metode pemipetan, sedangkan sedimen dasar pasir dianalisis dengan metode pengayakan. Jenis sedimen diketahui dengan plot persentase sedimen kedalam segitiga shepard. 


\section{Penentuan Jalur Peletakan Kabel}

Penentuan jalur kabel didasarkan pada data kedalaman sert topografi dasar laut. Penentuan jalur berdasarkan kriteria yang memudahkan proses pemasangan dan mempunyai jalur terpendek antar landing point. Kemudian dilakukan pengecekan terhadap data side scan sonar untuk memastikan jalur kabel aman dan tidak terdapat gangguan pada dasar perairan. Selanjutnya dibuat penampang profil dasar laut pada jalur kabel yang menjadi acuan untuk menentukan panjang kabel yang dibutuhkan serta menentukan titik stationing sebagai titik fiks dalam proses pemasangan kabel. Langkah terakhir yaitu menentukan jenis perlindungan kabel berdasarkan jenis sedimen dasar hasil interpretasi side scan sonar dan sampling sedimen dasar.

\section{HASIL}

\section{Pasang Surut}

Hasil pengukuran pasang surut lapangan dilakukan verifikasi dengan data pasang surut BIG pada stasiun pengamatan Pelabuhan Panjang, Lampung untuk memperoleh nilai MSL sebagai koreksi kedalaman serta mengetahui tipe pasang surut pada lokasi penelitian.

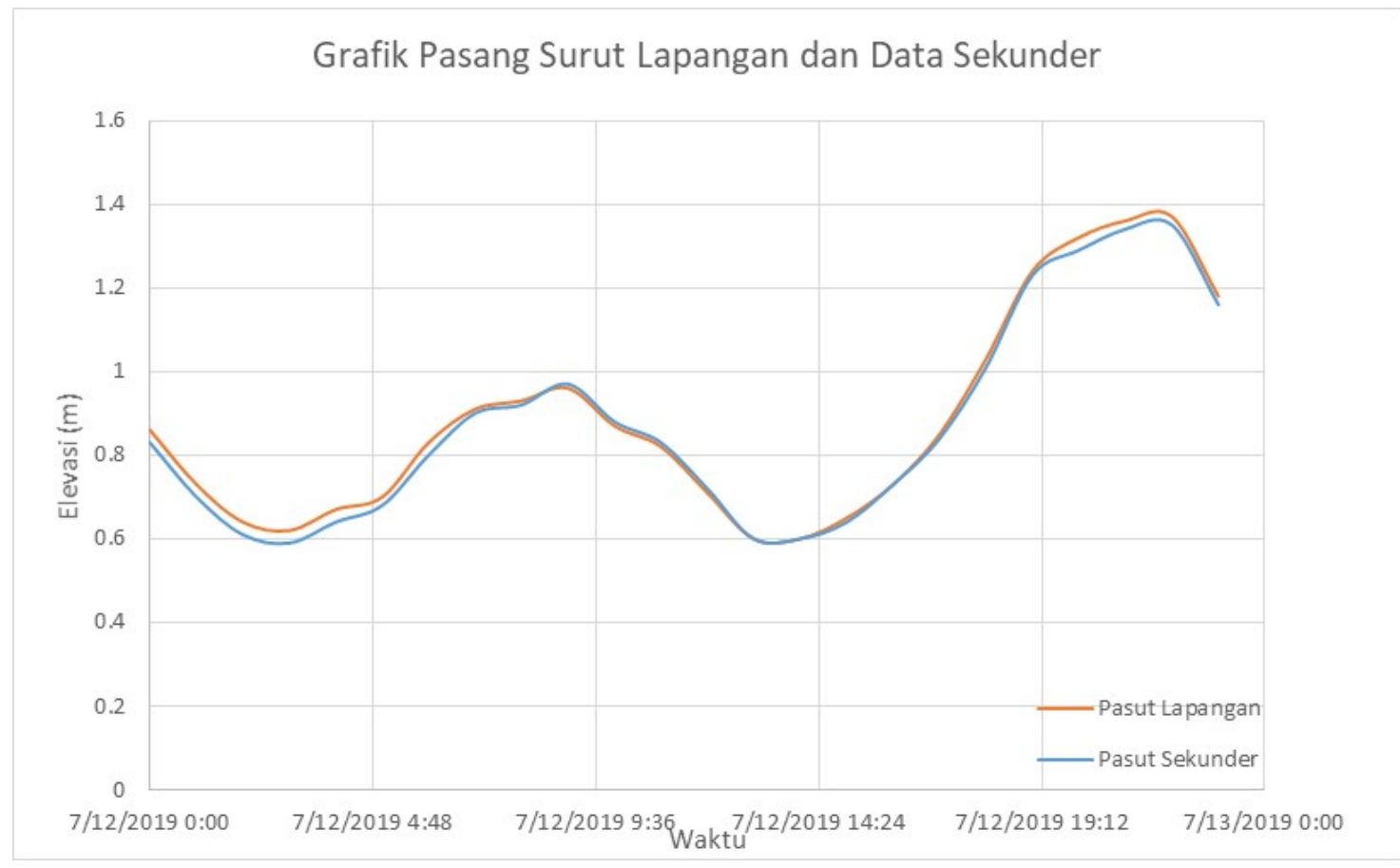

Gambar 1. Grafik Perbandingan Data Pasang Surut Lapangan dan Data Sekunder

Data pasang surut pada stasiun pengamatan Pelabuhan Panjang, Lampung diolah dengan metode Admiralty sehingga diketahui bahwa tipe pasang surut pada perairan tersebut yaitu tipe pasang surut campuran condong harian ganda dengan nilai Formzahl 0.47 dan komponen pasang surut sebagai berikut:

Tabel 2. Komponen Pasang Surut

\begin{tabular}{ccc}
\hline No & Komponen Pasang Surut & Nilai $(\mathrm{cm})$ \\
\hline 1 & $\mathrm{~S}_{0}$ & 84 \\
2 & $\mathrm{M}_{2}$ & 34 \\
3 & $\mathrm{~S}_{2}$ & 16 \\
4 & $\mathrm{~N}_{2}$ & 7 \\
5 & $\mathrm{~K}_{1}$ & 13 \\
6 & $\mathrm{O}_{1}$ & 10 \\
\hline
\end{tabular}




\begin{tabular}{ccc}
\hline 7 & $\mathrm{M}_{4}$ & 0 \\
8 & $\mathrm{MS}_{4}$ & 1 \\
9 & $\mathrm{~K}_{2}$ & 4 \\
10 & $\mathrm{P}_{1}$ & 4 \\
\hline
\end{tabular}

Kedudukan muka air laut pasang surut diperleh nilai elevasi pasang tinggi tertinggi (HHWL) sebesar 1.67 meter, nilai elevasi surut terendah (LLWL) sebesar 0.097 meter, dan nilai rata-rata muka air (MSL) sebesar $0.84 \mathrm{~m}$ yang menjadi acuan koreksi kedalaman.

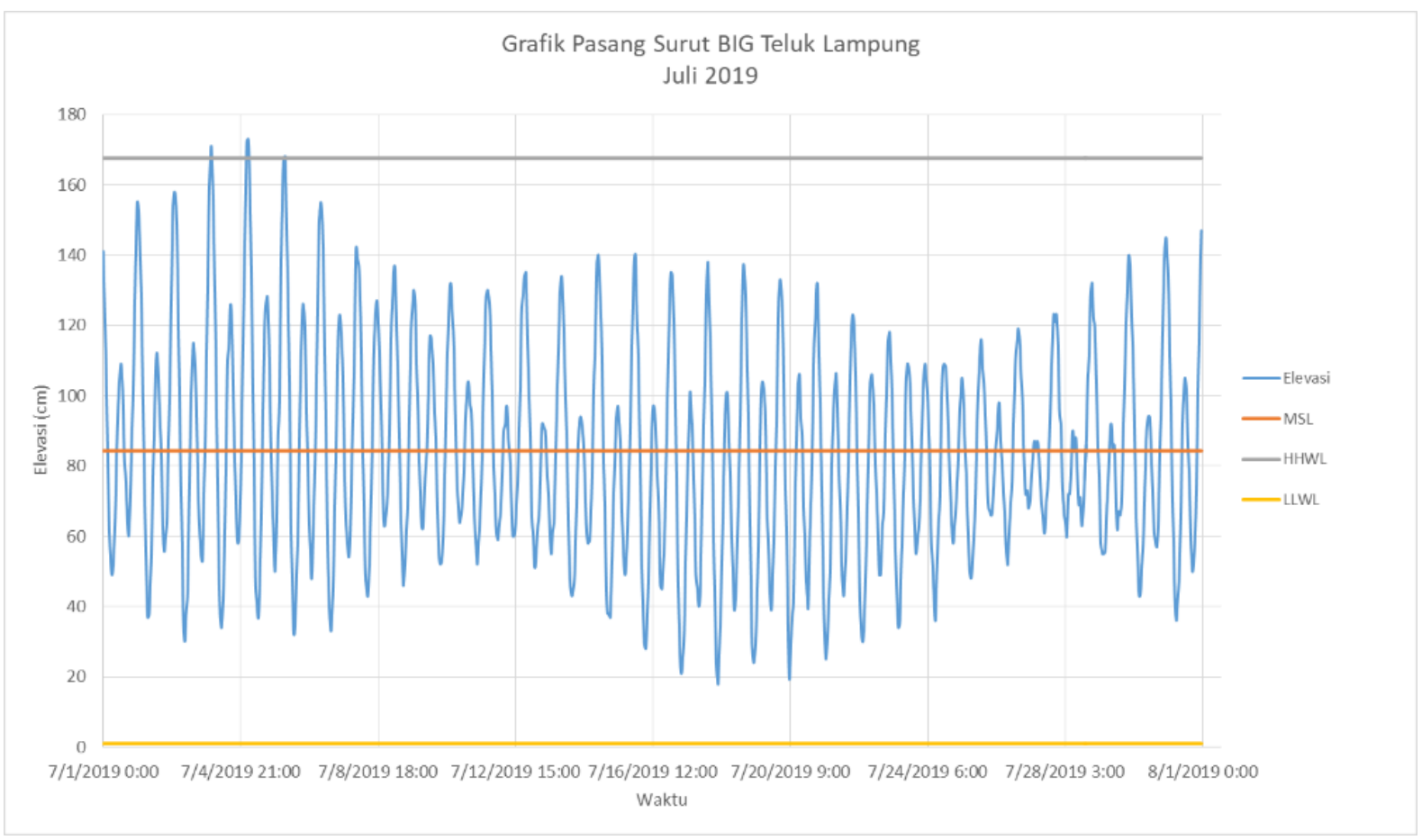

Gambar 2. Grafik Pasang Surut BIG Teluk Lampung Juli 2019

\section{Batimetri}

Data hasil pemeruman yang telah diolah menghasilkan titik fiks pemeruman berupa koordinat Latitude (X) dan Longitude (Y) serta nilai kedalaman (Z) yang terbaca oleh transducer. Hasil pengukuran batimetri dikoreksi dengan MSL pasang surut BIG seperti ditunjukkan pada Gambar 3 . Interval kontur kedalaman yang digunakan yaitu 1 meter untuk kontur minor dan 5 meter untuk kontur mayor. 


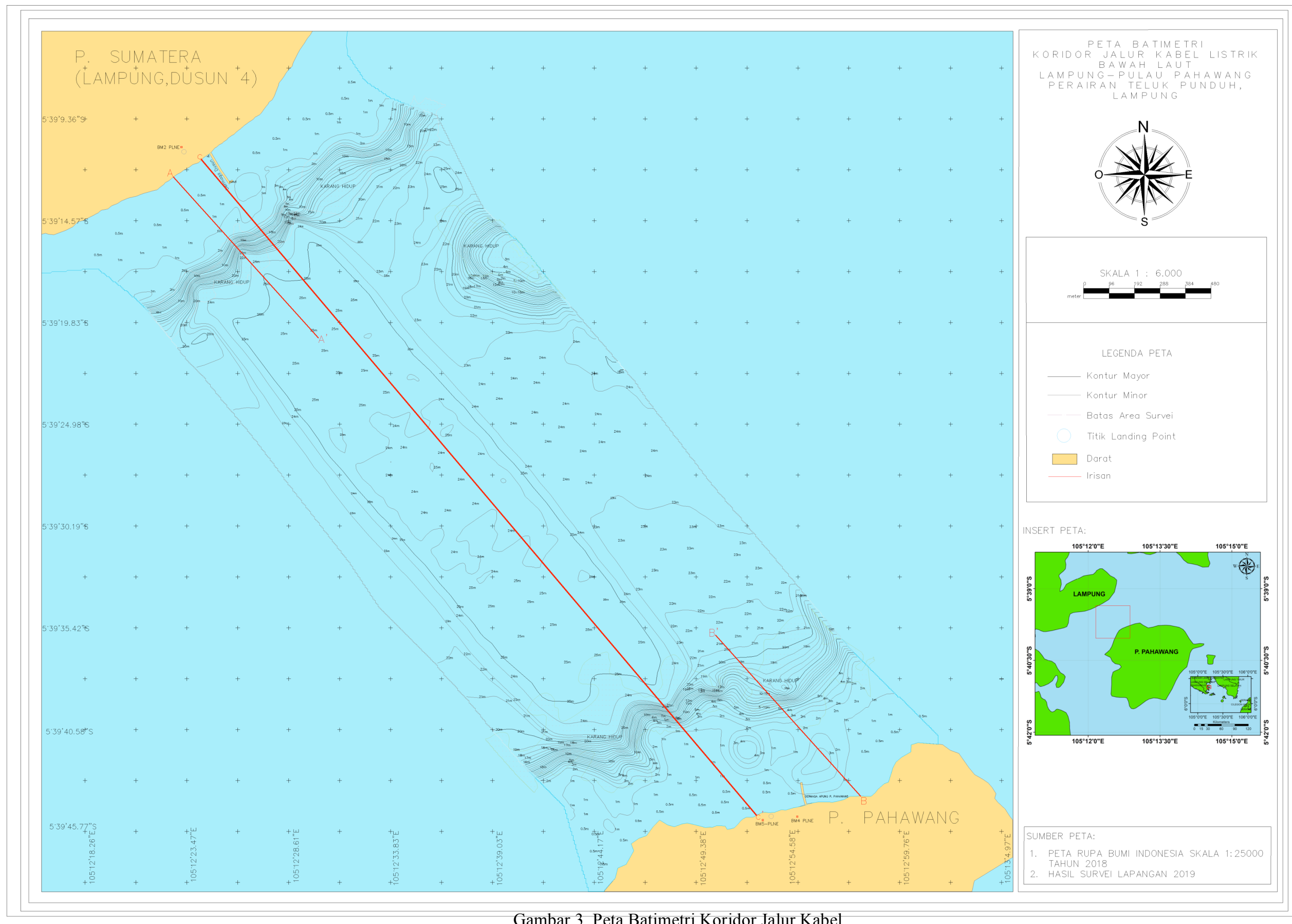

Gambar 3. Peta Batimetri Koridor Jalur Kabel 


\section{Kemiringan Lereng Dasar Laut}

Kemiringan lereng dasar laut divisualisasikan dalam penampang melintang garis A-A', B-B' dan C-C'. Nilai kemiringan akan menjadi acuan untuk menentukan jenis dasar perairan dengan menggunakan klasifikasi kemiringan menurut Van Zuidam (1985).

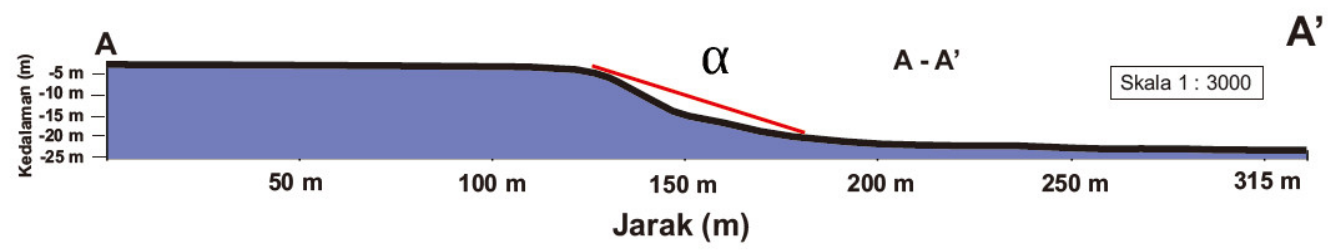

Gambar 4. Penampang Melintang Garis A-A’

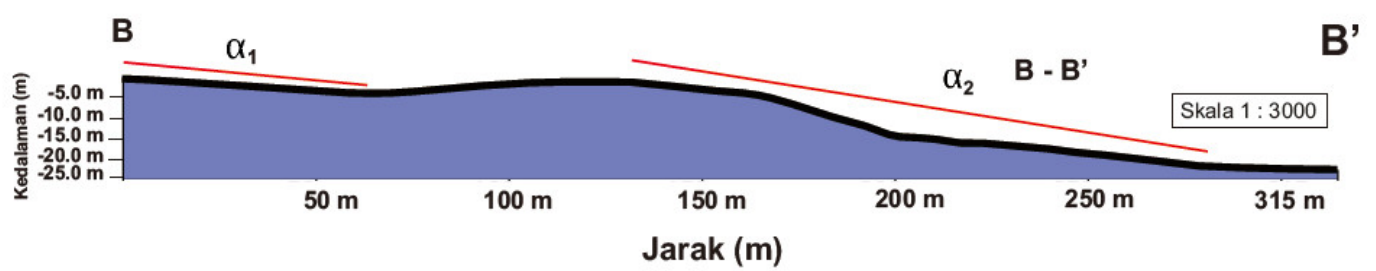

Gambar 5. Penampang Melintang Garis B-B'

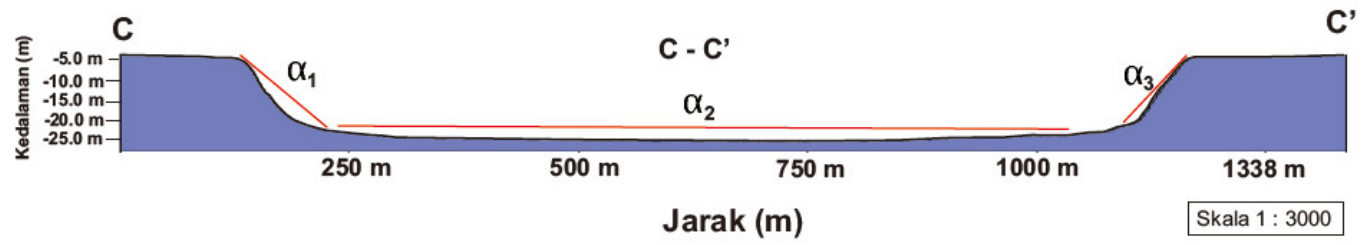

Gambar 6. Penampang Melintang Garis C-C'

Tabel 3. Hasil Perhitungan Kemiringan Dasar Laut

\begin{tabular}{|c|c|c|c|c|c|c|c|}
\hline Sayatan & segmen & $\begin{array}{c}\text { kedalaman } \\
\text { (meter) }\end{array}$ & $\begin{array}{c}\text { jarak } \\
\text { (meter) }\end{array}$ & $\tan \alpha$ & $\left({ }^{0}\right)$ & $\begin{array}{l}\text { Rata- } \\
\text { rata }\left(^{0}\right)\end{array}$ & $\begin{array}{c}\text { Klasifikasi Van } \\
\text { Zuidam }\end{array}$ \\
\hline A-A' & $\alpha$ & 24 & 50 & 0.48 & 25.6 & 25.6 & Curam \\
\hline \multirow{3}{*}{ B-B' } & $\alpha_{1}$ & 3.5 & 70 & 0.05 & 2.86 & \multirow{3}{*}{5.17} & \multirow{3}{*}{ Bergelombang } \\
\hline & & & & & & & \\
\hline & $\alpha_{2}$ & 20 & 152 & 0.1315 & 7.49 & & \\
\hline \multirow{3}{*}{ C-C' } & $\alpha_{1}$ & 17 & 94 & 0.1808 & 10.2 & \multirow{3}{*}{6.48} & \multirow{3}{*}{ Bergelombang } \\
\hline & $\alpha_{2}$ & 2 & 880 & 0.0022 & 0.13 & & \\
\hline & $\alpha_{3}$ & 15 & 93 & 0.1612 & 9.09 & & \\
\hline
\end{tabular}




\section{Topografi Dasar Laut}

Visualisasi topografi bawah laut dalam 3D ditunjukkan pada Gambar 7. Tujuan model 3D ini untuk mengetahui dan mempermudah dalam analisa topografi dasar laut pada koridor jalur kabel bawah laut Lampung - Pulau Pahawang.

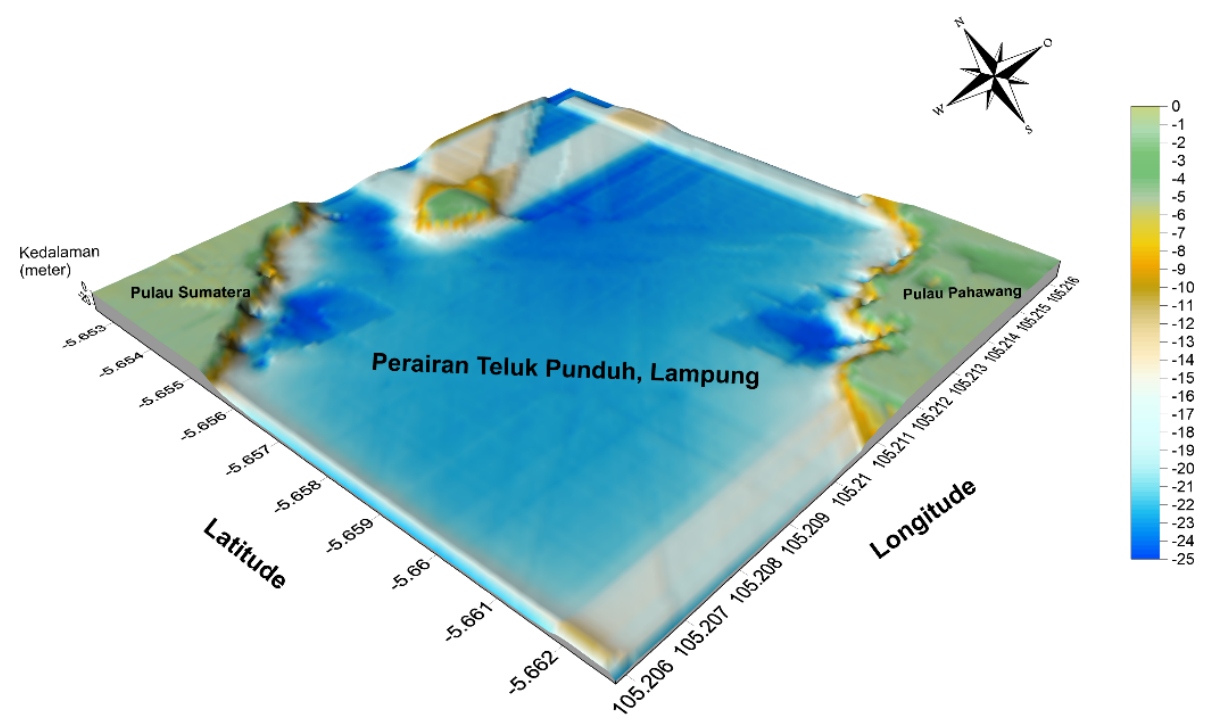

Gambar 7. Bentuk Model 3D Topografi Dasar Laut

\section{Jenis Sedimen Dasar Berdasar Interpretasi Side Scan Sonar}

Hasil side scan sonar berupa citra dasar laut di sepanjang koridor jalur kabel listrik bawah laut yang sama dengan jalur pemeruman batimetri. Hasil interpretasi jenis sedimen pada koridor jalur kabel ditunjukkan pada Gambar 8-11 berikut:

a. Jenis sedimen lumpur diinterpretasikan sebagai bentuk butiran kecil dengan pola tekstur halus dan memiliki rona saturasi yang cukup gelap, seperti ditunjukkan pada Gambar 6 berikut:

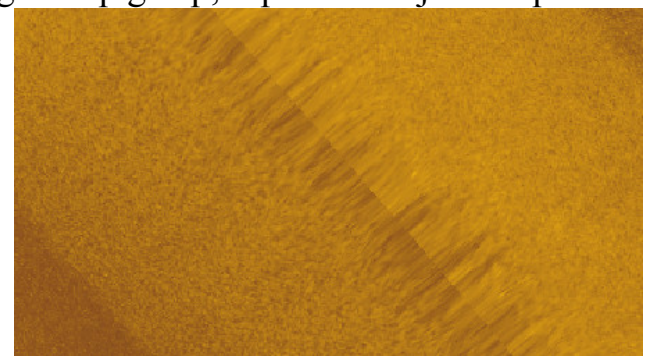

Gambar 8. Jenis Sedimen Lumpur Pada Citra Side Scan Sonar

b. Jenis sedimen lumpur berpasir diinterpretasikan dengan bentuk butiran kecil dengan pola tekstur halus dan memiliki rona saturasi yang sedang, ditunjukkan pada Gambar 7.

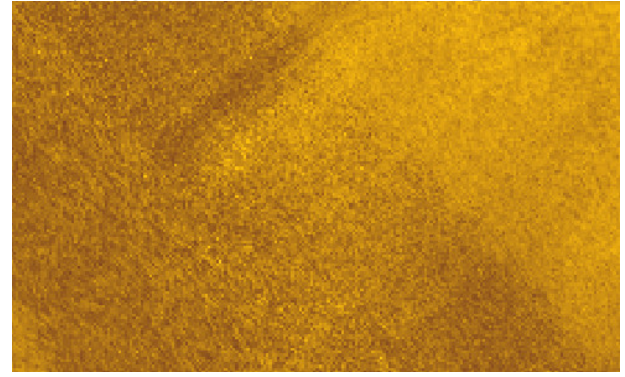

Gambar 9. Jenis Sedimen Lumpur Berpasir Pada Citra Side Scan Sonar 
c. Jenis sedimen pasir diinterpretasi dengan bentuk butiran kecil dengan pola tekstur halus dan memiliki rona saturasi terang.

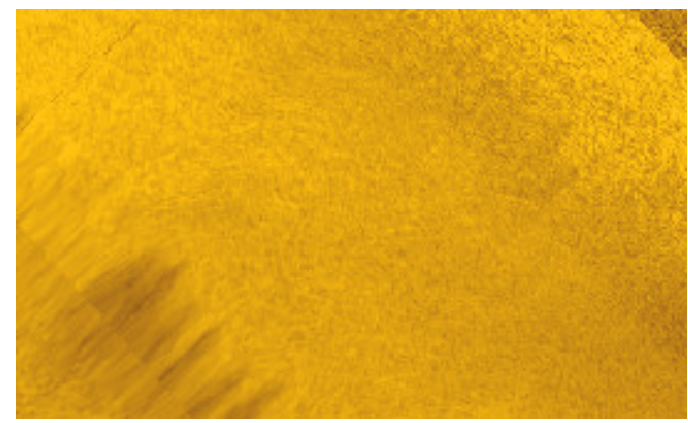

Gambar 10. Jenis Sedimen Pasir Pada Citra Side Scan Sonar

d. Fitur batuan keras atau karang diinterpretasi dengan bentuk bongkahan memanjang, rona saturasi terang dan terdapat shadow, serta memiliki pola tekstur mengelompok dan besar.
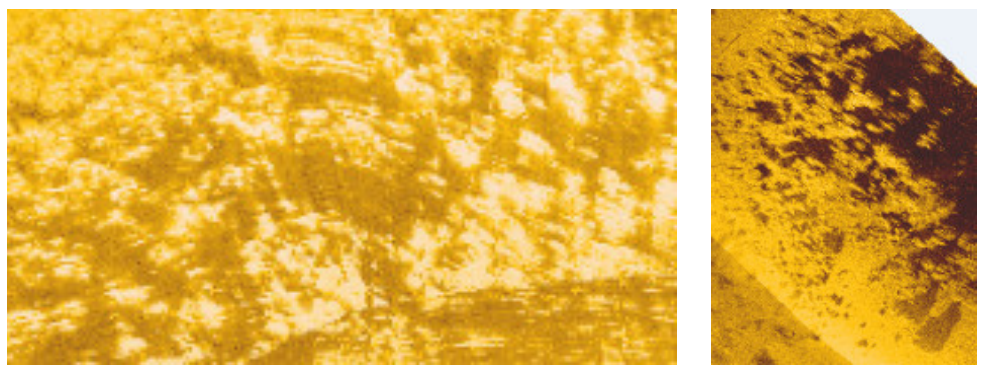

Gambar 11. Fitur Karang Pada Citra Side Scan Sonar 


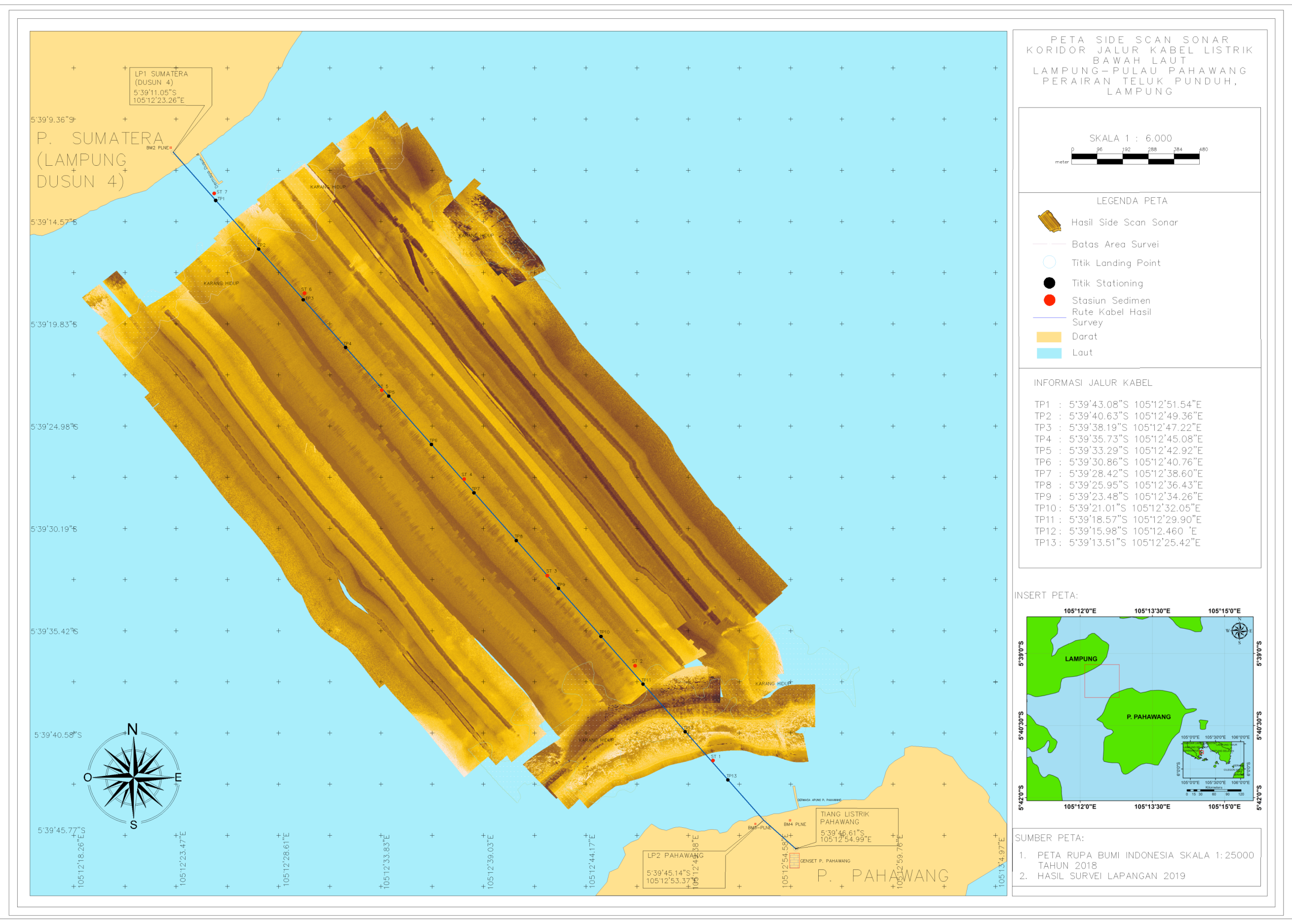

Gambar 12. Peta Side Scan Sonar 


\section{Analisis Ukuran Butir Sedimen}

Hasil pengolahan sampel sedimen dasar dengan metode pengayakan dan pemipetan pada tujuh stasiun menunjukkan jenis sedimen dominan berupa pasir dan lanau, seperti ditunjukkan pada Tabel 3. Hasil pengolahan sampel sedimen ini digunakan sebagai verifikasi jenis sebaran sedimen dengan menggunakan instrumen side scan sonar

Tabel 4. Jenis Sedimen Dasar di Koridor Jalur Kabel

\begin{tabular}{cccc}
\multirow{2}{*}{ Stasiun } & \multicolumn{2}{c}{ Koordinat Pengambilan Sampel } & \multirow{2}{*}{ Jenis Sedimen } \\
\cline { 2 - 3 } & Lintang & Bujur & \\
\hline 1 & -5.661955157 & 105.2142149 & Pasir \\
2 & -5.660670096 & 105.2128159 & Lanau \\
3 & -5.659209631 & 105.2116927 & Lanau \\
4 & -5.657653647 & 105.2110709 & Lanau \\
5 & -5.656358929 & 105.2095976 & Lanau \\
6 & -5.654996937 & 105.2082116 & Pasir \\
7 & -5.653526393 & 105.2073359 & Pasir \\
\hline
\end{tabular}

\section{Jalur Kabel Bawah Laut}

Penentuan jalur kabel listrik bawah laut didasarkan pada kriteria yang terlah ditetapkan yaitu harus aman dan memudahkan pemasangannya, serta memilih jalur terpendek baik berdasarkan jarak maupun panjang kabel mengikuti kemiringan dasar laut. Terdapat titik stationing dengan jarak 100 meter antar titiknya antar landing point. Koordinat titik stationing ditunjukkan pada Tabel 4 dan hasil panjang jalur kabel ditunjukkan pada Gambar 11 dan Gambar 12 berikut:

Tabel 5. Koordinat Titik Desain Jalur Kabel Laut antara landing point Lampung - Pulau Pahawang

\begin{tabular}{|c|c|c|c|}
\hline \multirow{2}{*}{ Ruas } & \multicolumn{3}{|c|}{ Titik Stationing } \\
\hline & $\mathbf{X}$ & $\mathbf{Y}$ & $\mathrm{Z}$ (m) \\
\hline TP 1 & $5^{\circ} 39^{\prime} 43.08^{\prime \prime S}$ & $105^{\circ} 12^{\prime} 51.54^{\prime \prime E}$ & -1 \\
\hline TP 2 & $5^{\circ} 39^{\prime} 40.63^{\prime \prime S}$ & $105^{\circ} 12^{\prime} 49.36^{\prime \prime} \mathrm{E}$ & -20 \\
\hline TP 3 & $5^{\circ} 39^{\prime} 38.19^{\prime \prime S}$ & $105^{\circ} 12^{\prime} 47.22^{\prime \prime} \mathrm{E}$ & -25 \\
\hline ТP 4 & $5^{\circ} 39^{\prime} 35.73 " \mathrm{~S}$ & $105^{\circ} 12^{\prime} 45.08^{\prime \prime} \mathrm{E}$ & -25 \\
\hline TP 5 & $5^{\circ} 39^{\prime} 33.29^{\prime \prime S}$ & $105^{\circ} 12^{\prime} 42.92^{\prime \prime} \mathrm{E}$ & -25 \\
\hline TP 6 & $5^{\circ} 39^{\prime} 30.86^{\prime \prime S}$ & $105^{\circ} 12^{\prime} 40.76^{\prime \prime} \mathrm{E}$ & -24 \\
\hline ТP 7 & $5^{\circ} 39^{\prime} 28.42 " \mathrm{~S}$ & $105^{\circ} 12^{\prime} 38.60^{\prime \prime} \mathrm{E}$ & -24 \\
\hline TP 8 & $5^{\circ} 39^{\prime} 25.95^{\prime \prime S}$ & $105^{\circ} 12^{\prime} 36.43^{\prime \prime E}$ & -25 \\
\hline ТР 9 & $5^{\circ} 39^{\prime} 23.48^{\prime \prime S}$ & $105^{\circ} 12^{\prime} 34.26^{\prime \prime} \mathrm{E}$ & -25 \\
\hline TP 10 & $5^{\circ} 39^{\prime} 21.01 " \mathrm{~S}$ & $105^{\circ} 12^{\prime} 29.90^{\prime \prime} \mathrm{E}$ & -25 \\
\hline TP 11 & $5^{\circ} 39^{\prime} 18.57^{\prime \prime S}$ & $105^{\circ} 12^{\prime} 29.90 " \mathrm{E}$ & -25 \\
\hline ТP 12 & $5^{\circ} 39^{\prime} 15.98^{\prime \prime S}$ & $105^{\circ} 12^{\prime} 27.60^{\prime \prime} \mathrm{E}$ & -2 \\
\hline TP 13 & $5^{\circ} 39^{\prime} 13.51^{\prime \prime S}$ & $105^{\circ} 12^{\prime} 25.42^{\prime \prime} \mathrm{E}$ & -1 \\
\hline
\end{tabular}




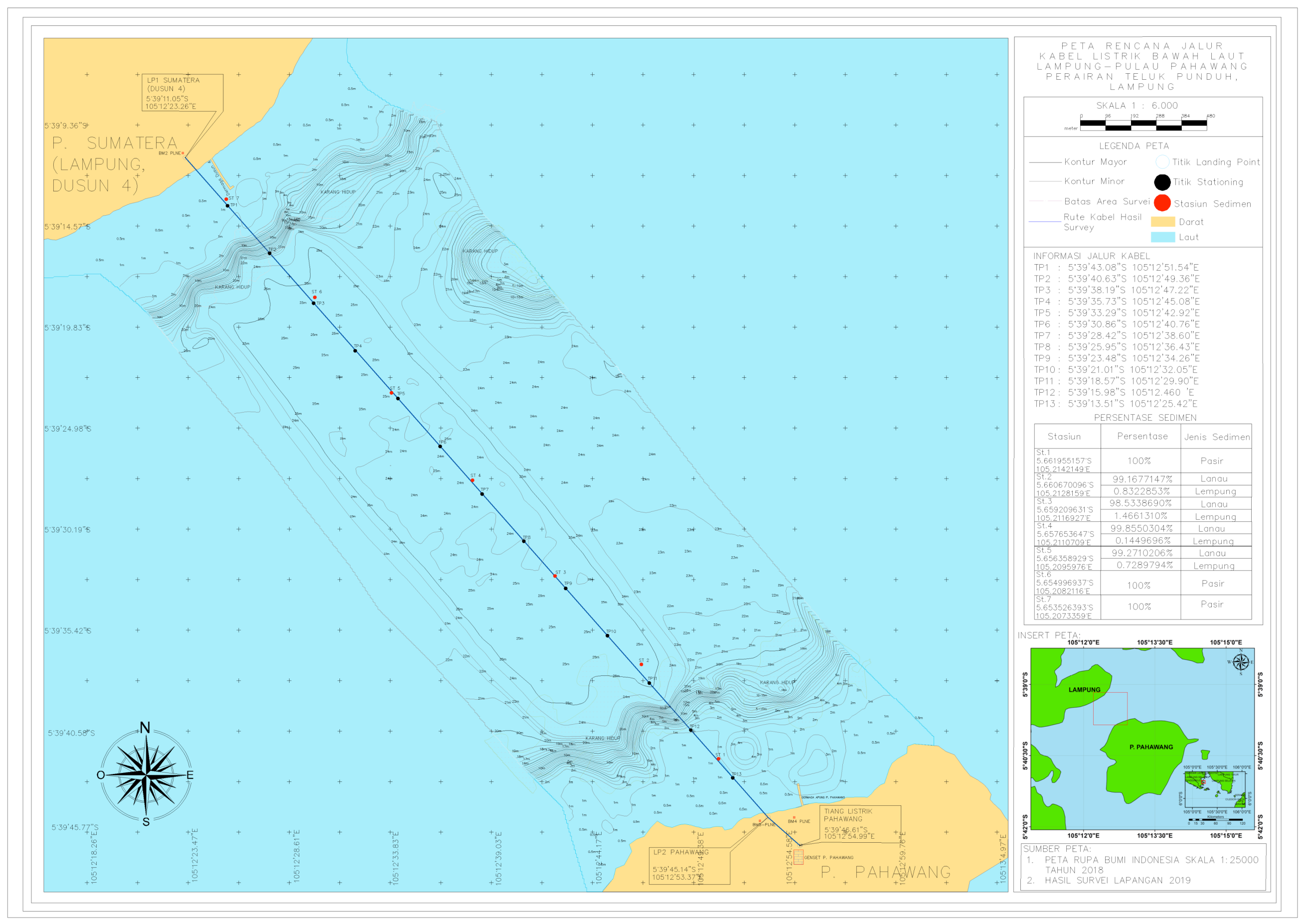




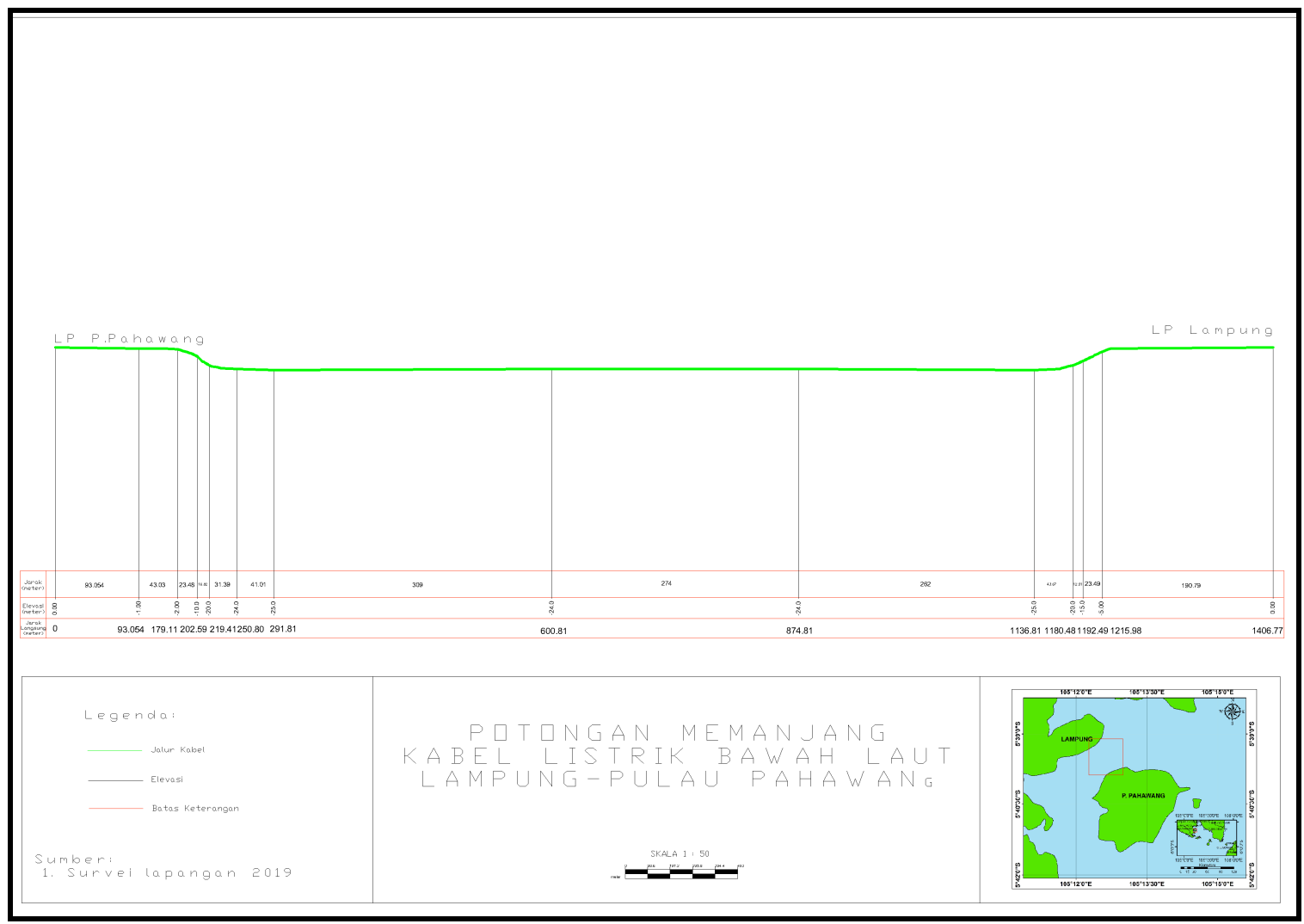

Gambar 14. Potongan Melintang Jalur Kabel

\section{PEMBAHASAN}

\section{Batimetri}

Berdasarkan hasil pengukuran kedalaman laut, terlihat bahwa sepanjang koridor jalur kabel listrik bawah laut memiliki kedalaman yang bervariasi antara -0.5 hingga - 25 meter. Nilai - nilai kedalaman yang diperoleh telah dikoreksi dengan data vertikal MSL pasang surut pada -0.84 meter. Variasi kedalaman ditunjukkan oleh adanya garis-garis kontur yang rapat dan tertutup yang menunjukkan bahwa pada dasar perairan terdapat gundukan atau perbedaan kedalaman yang cukup signifikan. Kerapatan yang tinggi juga menunjukkan bahwa terdapat kemiringan (slope) yang terjal, Sehingga dapat diketahui bahwa pada koridor jalur kabel listrik bawah laut Lampung - Pulau Pahawang memiliki tubir pantai yang cukup terjal bergelombang. Kedalaman laut suatu perairan dapat berubah terus menerus, hal ini disebabkan oleh kedalaman suatu perairan mengikuti perubahan ketinggian muka laut, sehingga diperlukan pengukuran kedalaman secara berkala untuk memperoleh data kedalaman laut yang aktual.

\section{Topografi dan Kemiringan Lereng Dasar Laut}

Hasil penampang melintang pada sayatan A-A' memiliki nilai kemiringan $25.6^{\circ}$ dan termasuk dalam klasifikasi dasar perairan curam. Sayatan B-B' menunjukkan nilai kemiringan $5.17^{\circ}$ yang termasuk dalam klasifikasi perairan dengan dasar bergelombang. Apabila ditinjau pada kemiringan sayatan A-A' terdapat kemiringan yang datar, namun juga terlihat perubahan kedalaman yang sangat drastis, sehingga membentuk pola dasar laut yang curam. Sedangkan pada sayatan B-B' terlihat bahwa dasar laut relatif lebih bergelombang. Pada sayatan $\mathrm{C}^{-} \mathrm{C}^{\prime}$ ditarik sayatan melintang lurus dari Lampung hingga Pulau Pawahang untuk merepresentasikan nilai kemiringan pada koridor jalur kabel bawah laut. Sayatan C-C' menunjukkan nilai kemiringan rata-rata $6.48^{\circ}$ yang termasuk dalam klasifikasi dasar perairan bergelombang. Hal ini menunjukkan bahwa pada koridor jalur kabel bawah laut LampungPulau Pahawang secara umum memiliki dasar perairan bergelombang.

Hasil model 3D topografi dasar laut sangat membantu dalam mengamati kondisi permukaan dasar laut pada daerah penelitian. Terlihat bahwa pada bagian timur Lampung menunjukkan adanya morfologi yang curam berupa terumbu karang dan cekungan yang tidak terlalu dalam, sedangkan pada bagian lainnya terlihat datar dan hanya curam pada area tubir pantai. Berdasarkan hasil tersebut koridor jalun 
kabel listrik bawah laut Lampung - Pulau Pahawang termasuk dalam topografi dasar laut continental shelf atau paparan benua dengan nilai kedalaman hingga -30 meter. Hal ini seperti pernyataan Kennet (1982) bahwa continental shelf merupakan dasar laut dangkal dengan kemiringan yang landai dan memiliki lereng yang curam dengan kedalaman rata-rata 30 meter.

Perbedaan bentuk topografi permukaan dasar laut disebabkan terutama oleh peristiwa tektonik. Disamping itu faktor oseanografi seperti gelombang, arus dan pasang surut juga ikut mempengaruhi jika dihubungkan dengan proses geologi resen. Mulyana dan Salahudin (2009) menyatakan bahwa pulau-pulau yang memiliki perbedaan bentuk relief yang menonjol dan dipisahkan oleh laut dalam, maka akan mempunyai palung-palung dalam dengan tatanan tektonik yang lebih rumit dibandingkan perairan yang landai.

\section{Citra Dasar Laut}

Visualisasi data side scan sonar pada kenampakan tekstur dasar laut terlihat memiliki bagian yang lebih kasar dan halus. Tekstur kasar memberikan sinyal hambur balik yang cerah dibandingkan dengan kenampakan tekstur halus dengan intensitas warna gelap yang mewakili daerah dengan hambur balik rendah. Interpretasi kualitatif berdasarkan citra dasar laut menunjukkan bahwa sedimen lumpur memiliki warna yang lebih gelap dibandingkan dengan pasir. Hal ini sesuai dengan pernyataan Amirullah et al (2015) bahwa citra side scan sonar memiliki hambur balik yang rendah ditunjukkan lebih gelap. Dominasi sedimen berdasarkan citra side scan sonar disepanjang koridor jalur kabel listrik bawah laut Lampung - Pulau Pahawang yaitu lumpur, lumpur berpasir, pasir dan karang.

Hasil citra side scan sonar koridor jalur kabel listrik bawah laut Lampung - Pulau Pahawang menunjukkan bahwa secara umum keadaan dasar laut yang terlihat tidak menampakkan obyek-obyek berbahaya yang dapat membahayakan kegiatan pemasangan kabel. Namun pada lokasi sekitar pantai terlihat bahwa terdapat terumbu karang yang cukup luas hingga menuju tubir pantai.

\section{Sebaran Sedimen Dasar Laut}

Berdasarkan hasil analisa sedimen dasar terhadap 7 contoh sedimen dasar yang diambil pada sepanjang koridor jalur kabel listrik bawah laut Lampung - Pulau Pahawang, menunjukkan bahwa sedimen di lokasi tersebut didominasi oleh substrat dasar berupa lanau dan pasir. Hasil analisis menunjukkan bahwa pada perairan yang dangkal sedimen didominasi oleh pasir dan semakin menuju laut sedimen didominasi oleh lanau. Hal ini dikarenakan oleh beberapa faktor yaitu faktor pergerakan arus di mana sedimen dengan ukuran butir lebih besar akan bergerak di dasar secara menggelinding (rolling), sedangkan lanau merupakan material yang mudah bergerak sehingga arus akan membawa sedimen kembali ke arah laut atau searah dengan arus. Apabila kecepatan arus berkurang, maka arus tidak mampu membawa sedimen dan akan terjadi sedimentasi di daerah tersebut (Triatmodjo, 1999). Selain itu faktor banyaknya terumbu karang di sekitar pantai menyebabkan sedimen dengan ukuran besar akan terperangkap dan tersedimentasi, sedangkan sedimen dengan ukuran kecil mampu melewatinya dan terendapkan di laut yang lebih dalam.

Hasil analisa sedimen ini menunjukkan adanya korelasi antara hasil side scan sonar dengan verifikasi sampel sedimen lapangan. Dimana jenis sedimen dasar hasil side scan sonar berupa lumpur, lumpur berpasir, pasir dan karang. Begitu pula dengan hasil analisa butir sedimen menunjukkan bahwa jenis sedimen dasar pada lokasi penelitian berupa lanau (lumpur) dan pasir. Perbedaan terletak pada jenis sedimen lumpur berpasir yang ditemui pada hasil side scan sonar dan tidak ditemui pada analisa ukuran butir sedimen. Hal disebabkan akibat beberapa faktor yaitu pengaruh titik pengambilan sampel yang terbatas pada 7 sampel dan titik sampel hanya berada di area tengah lokasi penelitian, sehingga jenis sedimen yang diperoleh dari verifikasi sampel sedimen hanya pada area tersebut.

Secara umum koridor jalur kabel listrik bawah laut Lampung - Pulau Pahawang termasuk dalam perairan dengan aktivitas yang rendah, sehingga faktor oseanografi yang terjadi mendukung ukuran butir lanau untuk mengendap pada dasar perairan.

\section{Jalur Kabel Bawah Laut}

Berdasarkan Keputusan Menteri Kelautan dan Perikanan Nomor: 33/MEN/2002, bahwa ditetapkan zona selebar 500 meter untuk sisi kiri dan kanan dari instalasi kabel dan pipa bawah laut sebagai zona yang terlarang untuk penambangan pasir. Lokasi penelitian berada pada daerah wisata 
sehingga aman dari area tambang pasir dan dapat digunakan untuk instalasi kabel listrik bawah laut. Kabel bawah laut juga di desain untuk melindungi bagian dalam dari air, tekanan tinggi, arus bawah laut dan gelombang serta fenomena alam lainnya yang mempengaruhi keadaan kondisi dasar laut dan air yang berada di atasnya, disamping itu sistem kabel bawah laut juga dapat bertahan 25-30 tahun setelah mulai dioperasikan (Tsutomu dan Nushiyama, 2010).

Hasil peta batimetri, peta side scan sonar dan topografi dasar laut digunakan untuk keperluan penentuan jalur kabel listrik bawah laut antara landing point Lampung dan landing point Pulau Pahawang. Desain jalur dibuat dengan pertimbangan dute pemasangan kabel yang paling optimal. Desain dimulai dari landing point Lampung menuju landing point Pulau Pahawang dengan pertimbangan berdasarkan Peraturan Menteri Perhubungan Nomor 129 Tahun 2016 Tentang Alur Pelayaran di Laut, sehingga jalur kabel pada lokasi penelitian diperoleh sebagai berikut:

1. Dari garis pantai sampai dengan kedalaman perairan 10 meter kabel tidak dapat dipendam di bawah permukaan perairan disebabkan oleh jenis sedimen pasir yang mudah terbawa oleh arus, sehingga pada lokasi ini digunakan concrete shell beton pada area berpasir dan cable coral clamp untuk mengikat kabel di area karang.

2. Pada perairan mulai kedalaman 10-15 meter instalasi kabel juga tidak dapat dipendam pada karena lokasi ini memiliki topografi yang curam dan bergelombang.

3. Pada perairan dengan kedalaman lebih dari 15 meter dan kurang dari 28 meter topografi datar dengan jenis sedimen lumpur, sehingga kabel dapat dipendam 0.5 meter.

4. Total panjang kabel pada desain jalur adalah 1406.77 meter, dengan perincian 375.83 meter adalah total panjang kabel dari kedalaman 0-10 meter, 33.37 meter adalah total panjang kabel kedalaman 10-15 meter, dan 997.61 meter adalah total panjang kabel dari kedalaman 15-25 meter.

\section{KESIMPULAN}

Berdasarkan hasil penelitian dan analisis pada koridor jalur kabel listrik bawah laut Lampung Pulau Pahawang, dapat disimpulkan bahwa:

1. Kondisi batimetri pada koridor kabel listrik bawah laut menunjukkan nilai kedalaman antara -0.5 meter hingga -25 meter, morfologi bergelombang dengan kemiringan $6.48^{\circ}$, serta sebaran sedimen dasar laut berupa lanau dan pasir.

2. Total panjang kabel listrik bawah laut sepanjang 1406.77 meter. Perlindungan kabel menggunakan concrete shell beton dan cable coral clamp pada kedalaman 0 - 10 meter sepanjang 375.83 meter, tanpa pemendaman pada kedalaman 10-15 meter sepanjang 33.37 meter, dan dipendam 0.5 meter pada kedalaman 15-25 meter sepanjang 997.61 meter.

\section{DAFTAR PUSTAKA}

Amirullah, M. D, Khomsin dan Danar, G. P. 2015. Analisis Data Sub Bottom Profiller Terintegrasi Untuk Identifikasi Sedimen. Jurnal Teknik ITS, 4(1).

Badan Pusat Statistik. 2018. Statistik Indonesia. Badan Pusat Statistik, Jakarta.

Det Norske Veritas (DNV-GL). 2016. Subsea Power Cables in Shallow Water. DNV-GL, AS.

Fitra, H. A dan Asirin. 2018. Ketahanan Masyarakat terhadap Ancaman Krisis Energi Listrik di Kabupaten Lampung Selatan, Provinsi Lampung. Jurnal Wilayah dan Lingkungan., 6(1): 58-73

Kennett, J. P. 1982. Marine Geology, Prentice-Hall Inc.,Englewood, New Jersey

Keputusan Menteri Kelautan dan Perikanan Nomor: 33/MEN/2002. Kementerian Kelautan dan Perikanan, Republik Indonesia.

Mulyana, W dan Salahudin, M. 2009. Morfologi Dasar Laut Indonesia. Puslitbang Geologi Kelautan (PPPGL), Dep. ESDM, Bandung

Peraturan Menteri Perhubungan Republik Indonesia. 2016. PM 129 Tahun 2016. Menteri Perhubungan, Republik Indonesia

Triatmodjo, B. 1999. Teknik Pantai. Beta Offset. Yogyakarta

Tsutomu, O dan Teomohisa, N. 2010. Route Design/Cable Laying Technologies for Optical Submarine Cable. NEC Technical Journal., 5(5): 46-50

Van Zuidam, R. A. 1985. Aerial Photo-Interpretation in Terrain Analysis and Geomorphology Mapping. Smith Publisher The Hague, ITC. 